\title{
Investigation of Structural Formation of Starting Composition 2245 in the Bi-Pb-Sr-Ca-Cu-O System Superconductors
}

\author{
Ashoka Nukkanahalli Venkataswamy, ${ }^{1}$ George Thomas Chirayil, \\ and Srinivasan Kannaiyan ${ }^{2}$ \\ ${ }^{1}$ Department of Physics, Christ University, Bangalore 560 029, India \\ ${ }^{2}$ Department of Physics, Government First Grade College, K R Puram, Bangalore 560 036, India \\ Correspondence should be addressed to George Thomas Chirayil; george.thomas.c@christuniversity.in
}

Received 5 June 2014; Revised 7 August 2014; Accepted 8 August 2014; Published 15 September 2014

Academic Editor: Veer P. S. Awana

Copyright (C) 2014 Ashoka Nukkanahalli Venkataswamy et al. This is an open access article distributed under the Creative Commons Attribution License, which permits unrestricted use, distribution, and reproduction in any medium, provided the original work is properly cited.

\begin{abstract}
Structural formation of $\mathrm{Bi}_{1.65} \mathrm{~Pb}_{0.35} \mathrm{Sr}_{2} \mathrm{Ca}_{4} \mathrm{Cu}_{5} \mathrm{O}_{y}$ (2245 phase) superconducting compound was investigated by preparing the sample in a new matrix route. The phases formed at different intervals of heat treatment are monitored by X-ray diffraction studies. Bi- 2212 phase was found to be the predominant phase till 20 hours of sintering at $850^{\circ} \mathrm{C}$ after which Bi-2223 phase was found to be the major phase. Traces of $\mathrm{Ca}_{2} \mathrm{PbO}_{4}$ were also noticed along with 2212 and 2223 phases. For the first time, the highest $T_{C}$ onset of $127 \mathrm{~K}$ with maximum superconducting volume fraction was observed for the sample sintered at $850^{\circ} \mathrm{C}$ for 30 hours in this preparation. Further sintering is found to deteriorate the $T_{C}$ onset value of the sample. There was no signature of the formation of 2234 or 2245 phase in this synthesis.
\end{abstract}

\section{Introduction}

The bismuth system superconductors are generally represented by the formula $\mathrm{Bi}_{2} \mathrm{Sr}_{2} \mathrm{Ca}_{n-1} \mathrm{Cu}_{n} \mathrm{O}_{2 n+4}$ with critical temperature $\left(T_{C}\right)$ values around $10 \mathrm{~K}, 80 \mathrm{~K}$, and $110 \mathrm{~K}$ for $n=1,2$, and 3 , respectively $[1,2]$. Among the above, $n=2$ member, namely, $\mathrm{Bi}_{2} \mathrm{Sr}_{2} \mathrm{Ca}_{1} \mathrm{Cu}_{2} \mathrm{O}_{8}$ (2212), is found to be the most stable one. Preparation of $n=3$ member, $\mathrm{Bi}_{2} \mathrm{Sr}_{2} \mathrm{Ca}_{2} \mathrm{Cu}_{3} \mathrm{O}_{10}$ (2223), as a single phase is extremely difficult because of the intergrowth of low $T_{C} 2212$ phase with 2223 phase. Many research groups have tried to synthesize 2223 compound as a single phase [3-8]. The addition of lead to the superconducting $\mathrm{Bi}-\mathrm{Sr}-\mathrm{Ca}-\mathrm{Cu}-\mathrm{O}$ compounds leading to the formation of 2223 phase has been reported by Wang et al. [5] . Shi et al. [6] have tried to synthesize 2223 phase by heating an off stoichiometric starting composition with excess $\mathrm{Ca}$ and $\mathrm{Cu}$. Sastry et al. [7] have tried the matrix method to obtain a single phase 2223 compound with a $T_{C} 120 \mathrm{~K}$. Though there were many attempts made to synthesize $n=4$ (2234) and $n=5(2245)$ members $[9,10]$, no conclusive evidence is available on the structure and $T_{C}$ values of the above phases.
In this paper we report the results of our attempt to synthesize the 2245 phase by solid state reaction method.

\section{Materials and Methods}

The sample $\mathrm{Bi}_{1.65} \mathrm{~Pb}_{0.35} \mathrm{Sr}_{2} \mathrm{Ca}_{4} \mathrm{Cu}_{5} \mathrm{O}_{y}$ was prepared by solid state reaction method as the combinations of two matrices $M_{1}$ and $\mathrm{M}_{2}\left(\mathrm{M}_{1}=\mathrm{Bi}_{1.65} \mathrm{~Pb}_{0.35} \mathrm{Sr}_{2} \mathrm{Cu}_{3} \mathrm{O}_{x}\right.$ and $\left.\mathrm{M}_{2}=2 \mathrm{Ca}_{2} \mathrm{CuO}_{3}\right)$. High purity $(99.9 \%) \mathrm{Bi}_{2} \mathrm{O}_{3}, \mathrm{PbO}, \mathrm{SrCO}_{3}, \mathrm{CaCO}_{3}$, and $\mathrm{CuO}$ powders were used as starting materials. The powders with the molar ratio of $[\mathrm{Bi}]:[\mathrm{Pb}]:[\mathrm{Sr}]:[\mathrm{Cu}]=1.65: 0.35: 2: 3$ $\left(\right.$ matrix $\left.\mathrm{M}_{1}\right)$ and $[\mathrm{Ca}]:[\mathrm{Cu}]=4: 2\left(\right.$ matrix $\left.\mathrm{M}_{2}\right)$ were separately prepared by thoroughly mixing the components for about an hour using an agate mortar and pestle. The final mixtures in powder form were kept in two alumina crucibles and calcined at $810^{\circ} \mathrm{C}$ for 16 hours in a tubular furnace. The calcined powders were reground and pressed into pellets of about $10 \mathrm{~mm}$ in diameter and 2 to $3 \mathrm{~mm}$ in thickness under a pressure of 5 tons $/ \mathrm{cm}^{2}$. These pellets of matrices $\mathrm{M}_{1}$ and $\mathrm{M}_{2}$ were sintered at $835^{\circ} \mathrm{C}$ for 40 hours with two intermediate grindings and pelletisation and then furnace 


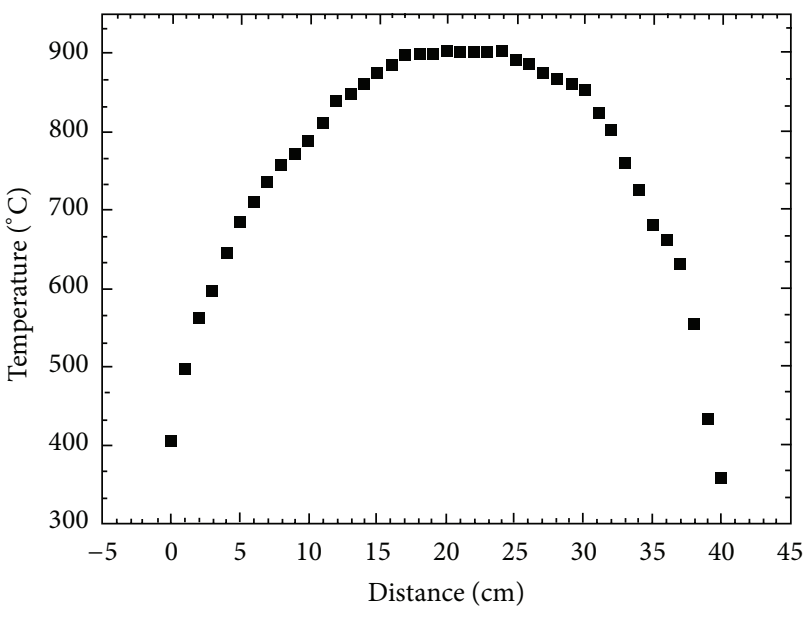

FIGURE 1: Temperature profile of the tubular furnace.

cooled to room temperature. One pellet of each sample was used for experimental measurements such as X-ray diffraction (XRD), SEM, and EDAX.

The two matrix samples $\mathrm{M}_{1}$ and $\mathrm{M}_{2}$ were mixed stoichiometrically into $\mathrm{M}_{12}$ sample of composition $\mathrm{Bi}_{1.65} \mathrm{~Pb}_{0.35} \mathrm{Sr}_{2} \mathrm{Ca}_{4}$ $\mathrm{Cu}_{5} \mathrm{O}_{y}$. The samples were well ground and mixed thoroughly into a fine powder. It is pressed into pellets of $10 \mathrm{~mm}$ diameter and 2 to $3 \mathrm{~mm}$ thick. These pellets were kept in a crucible and pulled along the axis of the tubular furnace at the rate of $1 \mathrm{~cm}$ per minute. The constant temperature region of the furnace was maintained at $900^{\circ} \mathrm{C}$ and it took about 40 minutes to pull the samples from one end to the other end of the furnace. The temperature profile along the axis of the tubular furnace is shown in Figure 1. Though a slight melting was observed on the surface of the pellets, all the pellets could be separated. These pellets were further sintered in air at $850^{\circ} \mathrm{C}$ for varying durations of 5 hours, 10 hours, and 15 hours, removing one pellet at the end of each interval after furnace cooling. The remaining pellets were ground, repelletised, and sintered at $850^{\circ} \mathrm{C}$ and one pellet each was removed as before at the end of total of 20 hours, 25 hours, 30 hours, and 40 hours, respectively. The removed pellets were labelled as $M_{12}$ (A, B, C, D, E, F, and G), respectively. For comparison, one more sample of the same composition was prepared by the usual solid state reaction route in which all the constituent compounds are mixed initially and calcined at $810^{\circ} \mathrm{C}$ for 20 hours, followed by sintering at $835^{\circ} \mathrm{C}$ for 45 hours with one intermediate grinding and pelletisation. This sample is labelled as P 2245.

One part of each pellet was cut, powdered, and used for X-ray diffraction, scanning electron microscopy (SEM), and energy dispersive $\mathrm{X}$-ray analysis (EDAX) measurements. Another piece of the pellet was used for $T_{C}$ measurement. The $T_{C}$ of the sample was determined by self-inductance method. A Colpitts oscillator and a frequency counter along with a liquid nitrogen cryostat were used for the purpose. The temperature of the sample was recorded using a calibrated chromel-alumel thermocouple with an accuracy of $\pm 1^{\circ} \mathrm{C}$. The $T_{C}$ of the samples were also confirmed by resistance measurement using the conventional four-probe method.
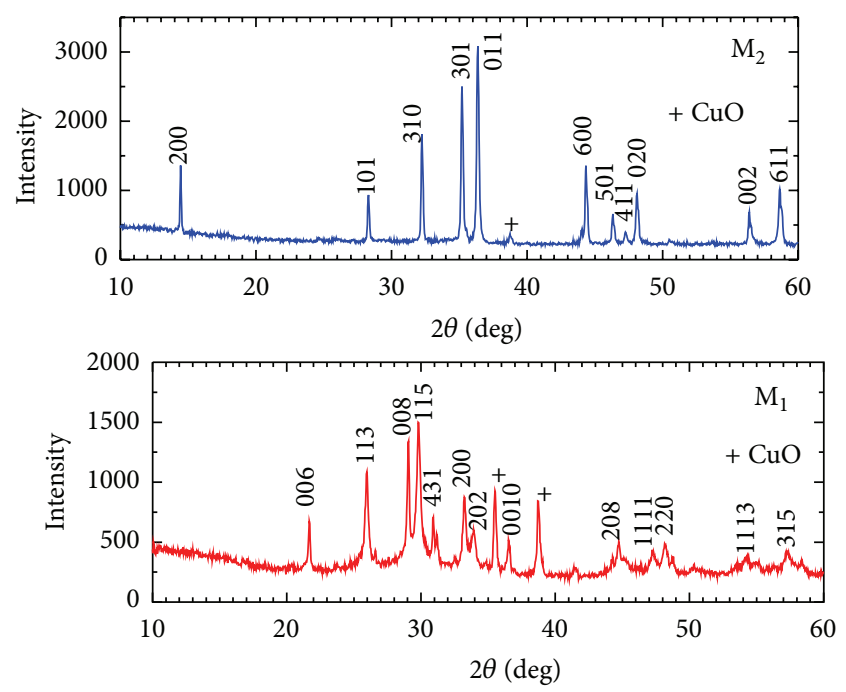

FIGURE 2: X-ray diffractogram of matrices $M_{1}$ and $M_{2}$.

\section{Results and Discussion}

The X-ray diffraction patterns of the matrices $M_{1}$ and $M_{2}$ are shown in Figure 2. The XRD of matrix $M_{1}$ indicates almost a single phase compound and is indexed in an orthorhombic cell with cell parameters $a=5.387 \AA, b=5.301 \AA$, and $c=24.574 \AA$. The XRD pattern is similar to the one obtained by Sinclair et al. [11]. Two peaks of unreacted $\mathrm{CuO}$ were also identified in the XRD pattern of $M_{1}$. All the peaks in the XRD pattern of matrix $\mathrm{M}_{2}$ (except one small peak at $2 \theta=38.74^{\circ}$ due to $\mathrm{CuO}$ ) were indexed in an orthorhombic cell with cell parameters $a=12.247 \AA, b=3.780 \AA$, and $c=3.259 \AA$. This pattern is similar to that of pure $\mathrm{Ca}_{2} \mathrm{CuO}_{3}$ compound identified with the ICDD XRD file (34-0282) as reported by Breuer et al. [12].

The XRD pattern of samples $\mathrm{M}_{12}(\mathrm{~A}, \mathrm{~B}, \mathrm{C}$, and $\mathrm{D})$ is indicated in Figure 3. The XRD pattern shows that majority of the peaks belong to 2212 phase (marked as L). Three peaks of $\mathrm{Ca}_{2} \mathrm{PbO}_{4}$ at $2 \theta=17.62^{\circ}, 31.06^{\circ}$, and $32.08^{\circ}$ have also been identified in $\mathrm{B}, \mathrm{C}$, and $\mathrm{D}$ patterns. It can be noted that peaks due to 2223 phase (marked as $\mathrm{H}$ ) gradually develop as the duration of heat treatment is increased. The analysis of XRD pattern of the samples $M_{12}$ (E, F, and G) (Figure 4) has shown an increase in cell parameter values and has been indexed in a tetragonal structure with $a \approx b \approx 5.4 \AA$ and $c \approx 37.2 \AA$. These peaks are due to the 2223 phase which has formed when the duration of heat treatment exceeded 20 hours at $850^{\circ} \mathrm{C}$. Figure 5 shows the XRD pattern of the sample P2245. Except for three peaks at $2 \theta=17.62^{\circ}, 31.06^{\circ}$, and $32.08^{\circ}$ of $\mathrm{Ca}_{2} \mathrm{PbO}_{4}$ all peaks are identified with that of 2223 phase. The lattice parameters of all the samples calculated from XRD data are given in Table 1.

The scanning electron microscope (SEM) images and superimposed EDAX spectra of samples $M_{1}$ and $M_{2}$ are represented in Figure 6. The EDAX spectra are in conformity with the atomic weight percentage of constituent elements as per the stoichiometry. As evident, SEM images reveal a granular and porous surface. The average grain size is 
TABLE 1: Heating profile and results of X-ray diffraction analysis of samples.

\begin{tabular}{|c|c|c|c|c|c|c|c|}
\hline \multirow{2}{*}{ Sample name } & \multicolumn{2}{|c|}{ History of heat treatment } & \multirow{2}{*}{$\begin{array}{c}a \\
\AA\end{array}$} & \multirow{2}{*}{$\begin{array}{l}b \\
\AA\end{array}$} & \multirow{2}{*}{$\begin{array}{l}c \\
\AA\end{array}$} & \multirow{2}{*}{$\begin{array}{l}\text { Cell volume } \\
\left(\times 10^{-30}\right) \mathrm{m}^{3}\end{array}$} & \multirow{2}{*}{$\begin{array}{l}\text { Grain size } \\
\text { (in } \mathrm{nm} \text { ) }\end{array}$} \\
\hline & Temperature $\left({ }^{\circ} \mathrm{C}\right)$ & Duration (hours) & & & & & \\
\hline $\mathrm{M}_{1}$ & 835 & 42 & 5.387 & 5.301 & 24.574 & 701.747 & 40.116 \\
\hline $\mathrm{M}_{2}$ & 835 & 42 & 12.247 & 3.780 & 3.259 & 150.871 & 74.570 \\
\hline $\mathrm{M}_{12} \mathrm{~A}$ & 850 & 5 & 5.393 & 5.421 & 30.788 & 900.200 & 61.139 \\
\hline $\mathrm{M}_{12} \mathrm{~B}$ & 850 & 10 & 5.389 & 5.395 & 30.767 & 894.580 & 75.690 \\
\hline $\mathrm{M}_{12} \mathrm{C}$ & 850 & 15 & 5.392 & 5.365 & 30.874 & 893.198 & 61.137 \\
\hline $\mathrm{M}_{12} \mathrm{D}$ & 850 & 20 & 5.401 & 5.391 & 30.775 & 896.255 & 72.250 \\
\hline $\mathrm{M}_{12} \mathrm{E}$ & 850 & 25 & 5.404 & 5.396 & 37.253 & 1086.570 & 63.580 \\
\hline $\mathrm{M}_{12} \mathrm{~F}$ & 850 & 30 & 5.398 & 5.402 & 37.220 & 1085.335 & 58.870 \\
\hline $\mathrm{M}_{12} \mathrm{G}$ & 850 & 40 & 5.390 & 5.415 & 37.216 & 1086.217 & 44.170 \\
\hline P 2245 & 835 & 45 & 5.423 & 5.407 & 37.003 & 1085.008 & 68.814 \\
\hline
\end{tabular}
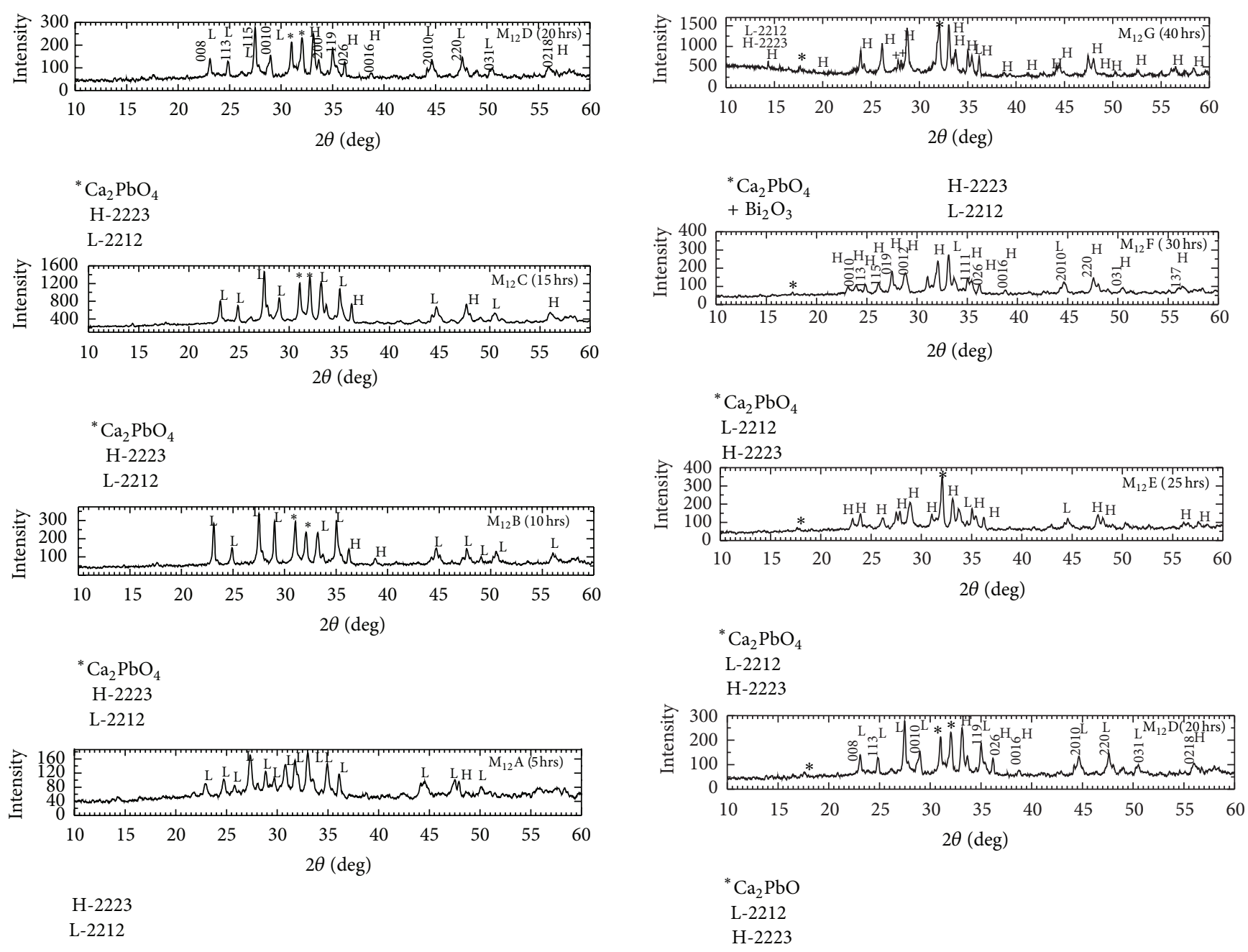

FIgURE 3: X-ray diffractogram of samples $\mathrm{M}_{12}$ (A, B, C, and D).

FIgURE 4: X-ray diffractogram of samples $\mathrm{M}_{12}$ (D, E, F, and G).

calculated from XRD data using Scherrer formula, $t=$ $0.89 \lambda / B \cos \theta_{B}$, where $t$ is the grain size, $\lambda$ is the wavelength of the X-rays, $\theta_{B}$ is the Bragg angle, and $B$ is the full width at half maximum (FWHM). SEM images of samples $\mathrm{M}_{12}$ (E, F, and G) and P 2245 are indicated in Figure 7. The variation of average grain size with duration of heating is shown in Figure 8 . The mean value of grain size is found to be about $60 \mathrm{~nm}$. 


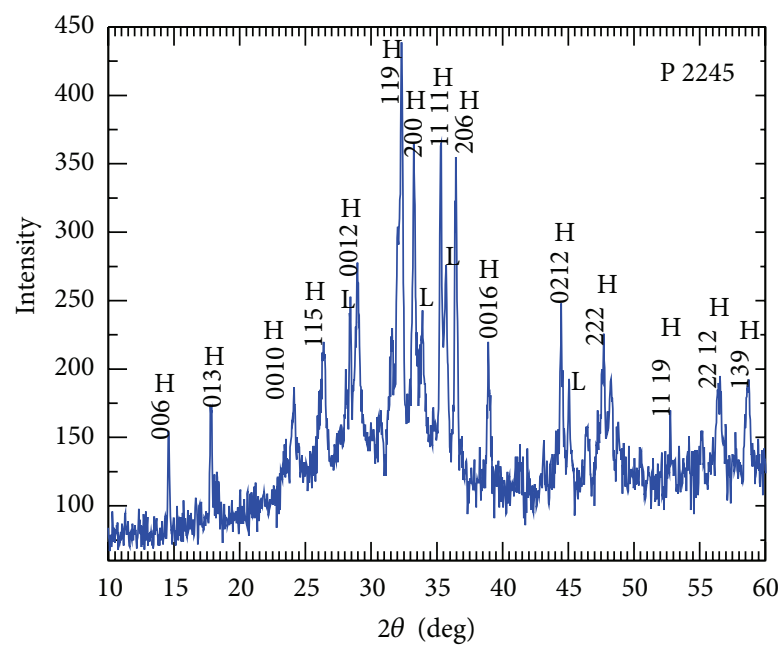

H-2223

L-2212

FIGURE 5: X-ray diffractogram of sample P 2245.

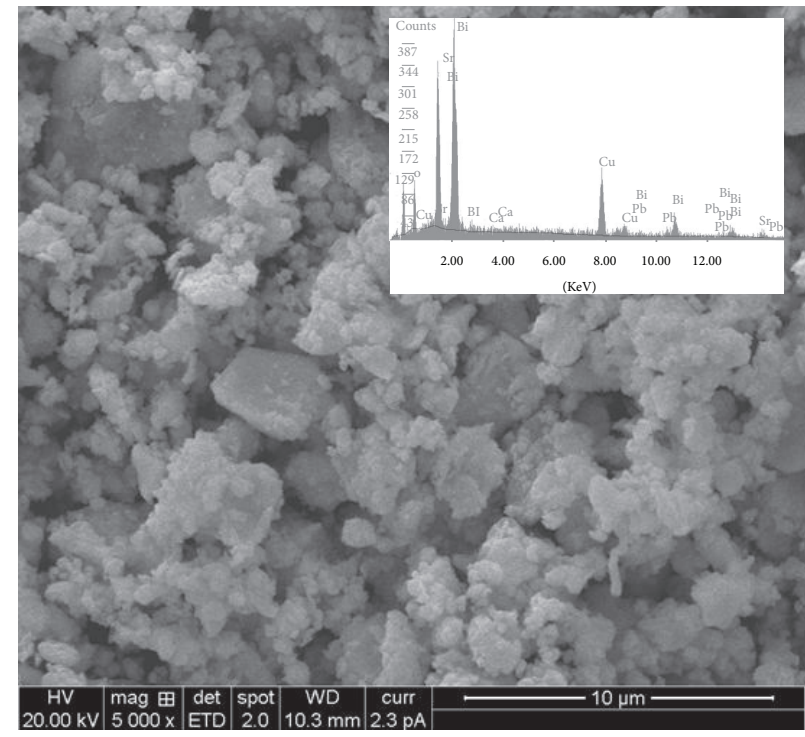

$\mathrm{M}_{1}$

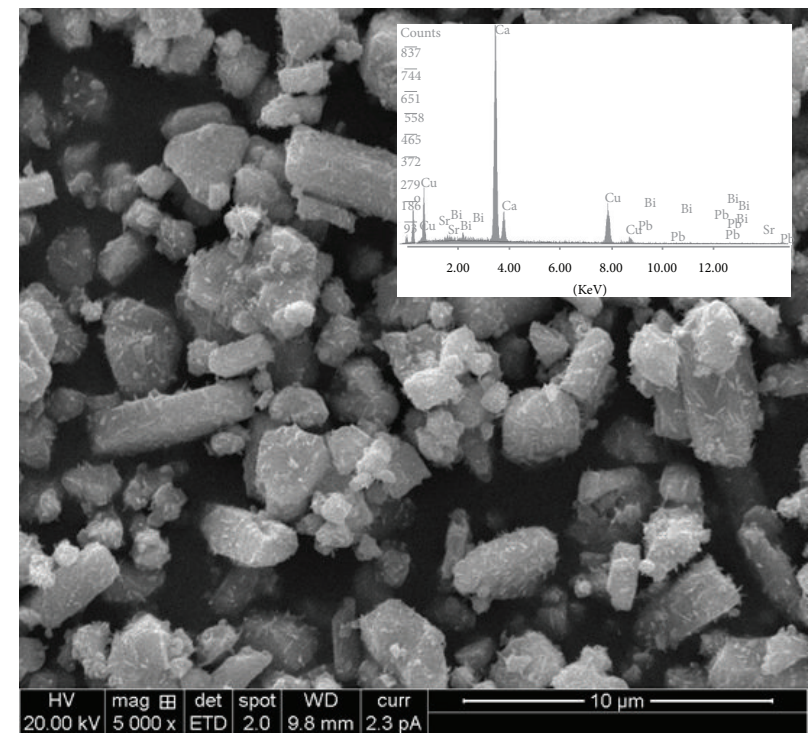

$\mathrm{M}_{2}$

FIGURE 6: SEM and EDAX images of the samples $M_{1}$ and $M_{2}$.

The normalised frequency $\left(f / f_{\mathrm{RT}}\right.$, where $f_{\mathrm{RT}}$ is room temperature frequency) of Colpitts oscillator versus temperature plots of the samples after different durations of heat treatment is represented in Figure 9. The normalised resistance $\left(R / R_{\mathrm{RT}}\right.$, where $R_{\mathrm{RT}}$ is the resistance at room temperature) versus temperature graph of selected samples is shown in Figure 10. Table 2 shows the $T_{C}$ values and identified phases in the prepared samples. The superconducting signature is observed in the sample only after 15 hours of sintering at $850^{\circ} \mathrm{C}$. The volume fraction of the superconducting phase gradually increases with increase in the duration of heat treatment which is evident from the steeper transitions (Figure 9, $M_{12} C$ and D). The major phase present in the sample after 20 hours of heating is 2212 phase. The sample heated for 25 hours at $850^{\circ} \mathrm{C}$ shows a two-step transition, one around $125 \mathrm{~K}$ (2223 phase) and another at around $105 \mathrm{~K}$ (2212 phase). The corresponding XRD pattern (Figure 4, $\mathrm{M}_{12} \mathrm{E}$ ) confirms this observation. The maximum value of $T_{C}$ onset $(127 \mathrm{~K})$ was observed for the sample heated for 30 hours (Figure $9, M_{12} F$ ). The sample heated for 40 hours shows the $T_{C}$ onset at $125 \mathrm{~K}$ but the volume fraction of the superconducting phase has decreased drastically which is 


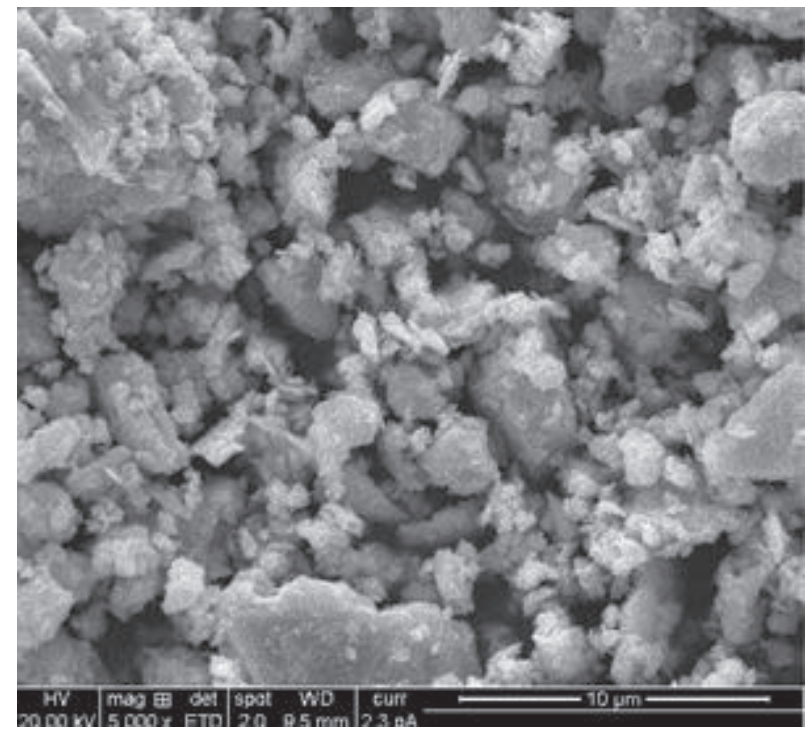

$\mathrm{M}_{12} \mathrm{E}$

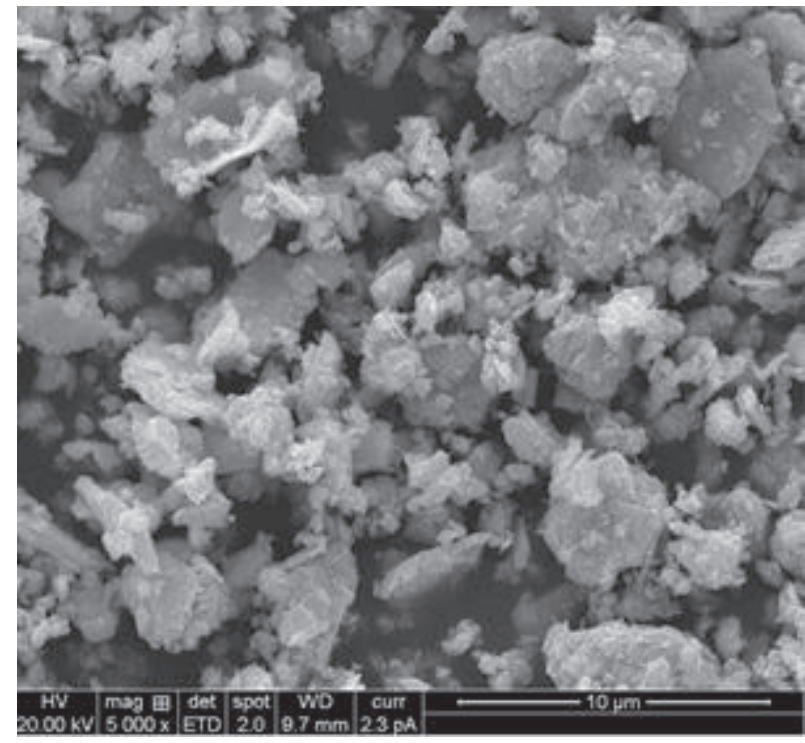

$\mathrm{M}_{12} \mathrm{G}$
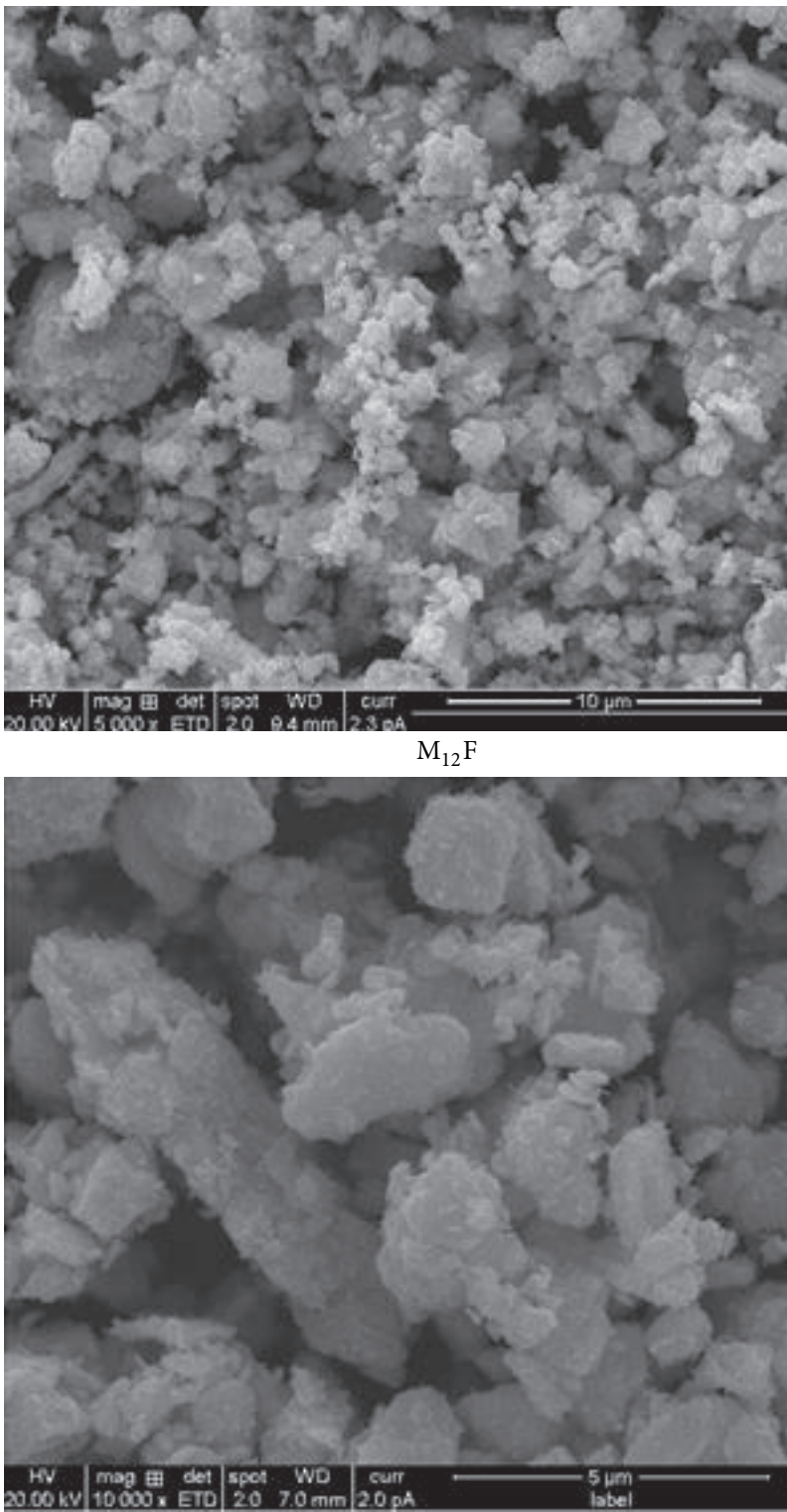

P 2245

FIgURE 7: SEM images of the samples $\mathrm{M}_{12}$ (E, F, and G) and P 2245.

TABLE 2: $T_{C}$ values and identified phases in the samples.

\begin{tabular}{|c|c|c|c|c|c|c|}
\hline \multirow{2}{*}{ Sample } & \multirow{2}{*}{$\begin{array}{l}\text { Sintering at } 850^{\circ} \mathrm{C} \\
\text { (hours) }\end{array}$} & \multirow{2}{*}{$\begin{array}{l}\text { Phases identified } \\
\text { from XRD }\end{array}$} & \multicolumn{2}{|c|}{ Colpitts oscillator } & \multicolumn{2}{|c|}{ Four-probe } \\
\hline & & & $T_{C}$ onset $(\mathrm{K})$ & $T_{C}(\mathrm{~K})$ & $T_{C}$ onset $(\mathrm{K})$ & $T_{C}$ zero $(\mathrm{K})$ \\
\hline $\mathrm{M}_{12} \mathrm{~A}$ & 5 & $2212,2223, \mathrm{Ca}_{2} \mathrm{PbO}_{4}$ & & & & \\
\hline $\mathrm{M}_{12} \mathrm{~B}$ & 10 & $2212,2223, \mathrm{Ca}_{2} \mathrm{PbO}_{4}$ & & & & \\
\hline $\mathrm{M}_{12} \mathrm{C}$ & 15 & $2212,2223, \mathrm{Ca}_{2} \mathrm{PbO}_{4}$ & 110 & - & - & - \\
\hline $\mathrm{M}_{12} \mathrm{D}$ & 20 & $2212,2223, \mathrm{Ca}_{2} \mathrm{PbO}_{4}$ & 120 & - & - & - \\
\hline $\mathrm{M}_{12} \mathrm{E}$ & 25 & $2223,2212, \mathrm{Ca}_{2} \mathrm{PbO}_{4}$ & 124 & 107 & 125,111 & 95 \\
\hline $\mathrm{M}_{12} \mathrm{~F}$ & 30 & 2223, 2212, $\mathrm{Ca}_{2} \mathrm{PbO}_{4}$ & 127 & 110 & 127,115 & 105 \\
\hline $\mathrm{M}_{12} \mathrm{G}$ & 40 & $2223,2212, \mathrm{Ca}_{2} \mathrm{PbO}_{4}, \mathrm{Bi}_{2} \mathrm{O}_{3}$ & 122 & 100 & 121 & 105 \\
\hline P 2245 & 45 & 2223,2212 & 119 & 100 & 120 & 100 \\
\hline
\end{tabular}




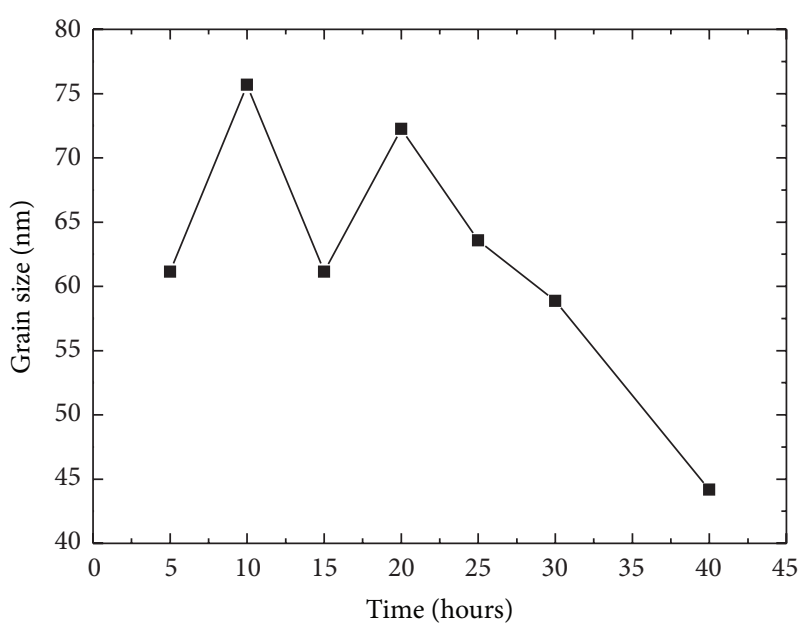

FIGURE 8: Grain size versus duration of heating.

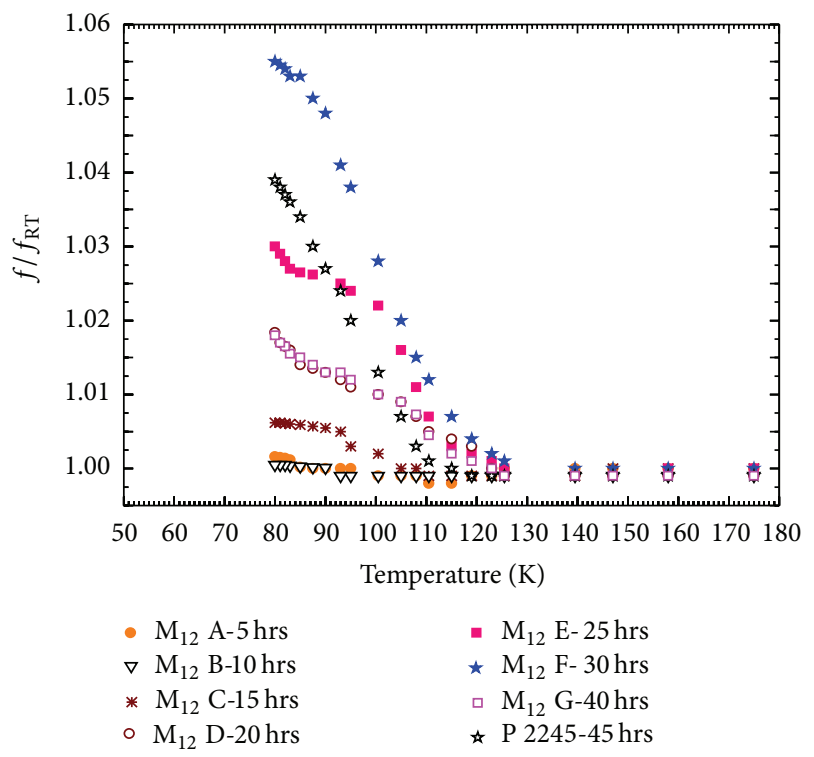

FIGURE 9: Normalised frequencies versus temperature curves of samples.

evident from the relatively smaller change in frequency. The XRD pattern of this sample (Figure $4, \mathrm{M}_{12} \mathrm{G}$ ) also shows two peaks at $2 \theta=27.8^{\circ}$ and $28.1^{\circ}$, respectively, which are identified with that of $\mathrm{Bi}_{2} \mathrm{O}_{3}$. Therefore, it is inferred that prolonged heating up to 40 hours has resulted in some $\mathrm{Bi}_{2} \mathrm{O}_{3}$ coming out of the structure and hence the decrease in volume fraction of the superconducting phase. The $T_{C}$ values measured by fourprobe method also shows similar values which are tabulated in Table 2.

The $T_{C}$ value of cuprate superconductors is known to vary with oxygen stoichiometry and is found to be a maximum for an optimum value of oxygen content. This can be manifested in terms of partial change of the valence state of copper from $\mathrm{Cu}^{2+}$ to $\mathrm{Cu}^{3+}$ in the $\mathrm{Bi}$ system superconductors [13-16].

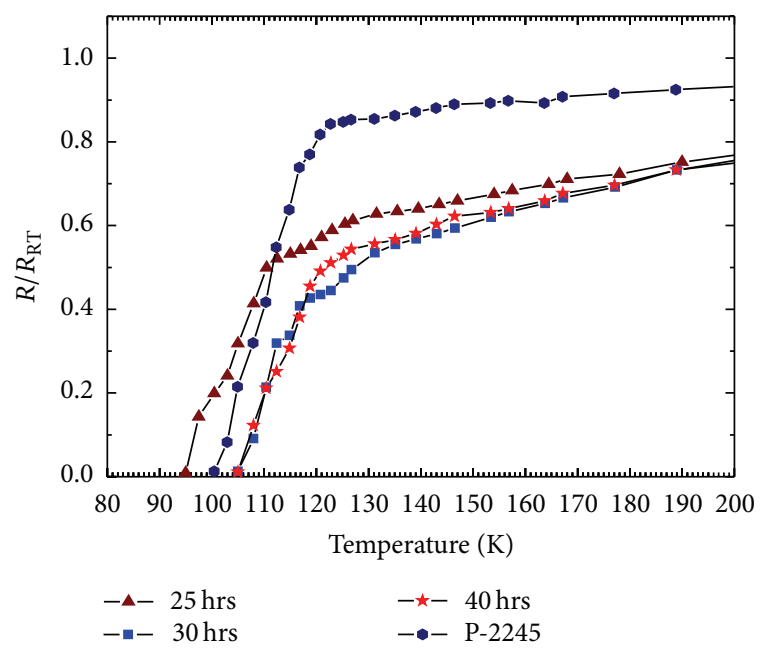

FIGURE 10: Normalised resistance versus temperature curves of the selected samples.

\section{Conclusions}

We synthesised $\mathrm{Bi}_{1.65} \mathrm{~Pb}_{0.35} \mathrm{Sr}_{2} \mathrm{Ca}_{4} \mathrm{Cu}_{5} \mathrm{O}_{y}$ superconductor by the matrix method with a new sintering cycle. The sample was initially heated at a comparatively high temperature of $900^{\circ} \mathrm{C}$ for a short duration followed by sintering at $850^{\circ} \mathrm{C}$ for different durations. The formation of the different phases as a function of duration of heat treatment was monitored. The $\mathrm{X}$-ray diffraction analysis of the prepared samples revealed the presence of predominantly 2212 phase when sintered at $850^{\circ} \mathrm{C}$ for 20 hours. Further sintering at the same temperature for 25 hours, 30 hours, and 40 hours, respectively, resulted in the formation of the 2223 phase as the major component. But after 40 hours of sintering, $\mathrm{Bi}_{2} \mathrm{O}_{3}$ was noticed to be coming out of the structure. The highest $T_{C}$ onset value $(127 \mathrm{~K})$ with maximum superconducting volume fraction was found for the sample sintered at $850^{\circ} \mathrm{C}$ for 30 hours. The presence of $\mathrm{Ca}_{2} \mathrm{PbO}_{4}$ is noticed in all samples which are preheated at $900^{\circ} \mathrm{C}$. No traces of 2234 or 2245 phase were noticed under the above preparation conditions.

\section{Conflict of Interests}

The authors declare that there is no conflict of interests regarding the publication of this paper.

\section{References}

[1] J. M. Tarascon, W. R. McKinnon, P. Barboux et al., "Preparation, structure, and properties of the superconducting compound series $\mathrm{Bi}_{2} \mathrm{Sr}_{2} \mathrm{Ca}_{n-1} \mathrm{Cu}_{n} \mathrm{O}_{y}$ with $n=1,2$, and 3," Physical Review $B$, vol. 38, no. 13, pp. 8885-8892, 1988.

[2] A. Maeda, K. Noda, K. Uchinokura, and S. Tanaka, "Study on the preparation and the physical properties of a $110 \mathrm{~K}(\mathrm{Bi}$, $\mathrm{Pb})_{2} \mathrm{Sr}_{2} \mathrm{Ca}_{2} \mathrm{Cu}_{3} \mathrm{O}_{y}$ superconductor," Japanese Journal of Applied Physics, vol. 28, article L576, 1989.

[3] A. Oota, Y. Sasaki, and A. Kirihigashi, "Superconductivity at $100 \mathrm{~K}$ in Bi-Pb-Sr-Ca-Cu-O," Japanese Journal of Applied Physics, vol. 27, p. L1445, 1988. 
[4] B. W. Statt, Z. Wang, M. J. G. Lee et al., "Stabilizing the high$T_{c}$ superconductor $\mathrm{Bi}_{2} \mathrm{Sr}_{2} \mathrm{Ca}_{2} \mathrm{Cu}_{3} \mathrm{O}_{10+x}$ by $\mathrm{Pb}$ substitution," Physica C: Superconductivity, vol. 156, no. 2, pp. 251-255, 1988.

[5] N. L. Wang, M. C. Tan, J. S. Wang, and Q. R. Zhang, "Cation substitution in $\mathrm{BiSrCaCuO}$ system," Physica C, vol. 185-189, no. 2, pp. 799-800, 1991.

[6] D. Shi, M. Tang, K. Vandervoori, and H. Claus, "Formation of the $110-\mathrm{K}$ superconducting phase via the amorphous state in the Bi-Sr-Ca-Cu-O system," Physical Review B, vol. 39, p. 9091, 1989.

[7] P. V. P. S. S. Sastry, J. V. Yakhmi, and R. M. Iyer, "On the synthesis and structure of single-phase $(\mathrm{Bi}, \mathrm{Pb})_{2} \mathrm{Ca}_{2} \mathrm{Sr}_{2} \mathrm{Cu}_{3} \mathrm{O}_{10}$," Bulletin of Materials Science, vol. 14, no. 2, pp. 223-226, 1991.

[8] R. Ramesh, G. Thomas, S. Green et al., "Polytypoid structure of $\mathrm{Pb}$-modified Bi-Ca-Sr-Cu-O superconductor," Physical Review $B$, vol. 38, no. 10, pp. 7070-7073, 1988.

[9] D. D. Gulamova, D. E. Uskenbaev, D. G. Chigvinadze, and O. V. Magradze, "Crystallization and synthesis of HTSC of compositions 2234, 2245 in the Bi-Pb-Sr-Ca-Cu-O system based on amorphous precursors obtained by solar radiation hardening," Applied Solar Energy, vol. 44, no. 1, pp. 42-45, 2008.

[10] S. Meretliev, K. B. Sadykov, and A. Berkeliev, "Doping of hightemperature superconductors," Turkish Journal of Physics, vol. 24, no. 1, pp. 39-48, 2000.

[11] D. Sinclair, J. Irvine, and A. West, Journal of Materials Research, vol. 7, pp. 43-47, 1992.

[12] E. Breuer, W. Mineral-Petrograph Inst. Univ. Heidelberg, Germany. ICDD file No. 34-0282, 1981.

[13] J. L. Tallon, R. G. Buckley, P. W. Gilbert, and M. R. Presland, "Single-phase $\mathrm{Pb}$-substituted $\mathrm{Bi}_{2+y} \mathrm{Ca}_{n-1} \mathrm{Sr}_{2} \mathrm{Cu}_{n} \mathrm{O}_{2 n+4+\delta}, n=$ 2 and 3: Structure, $\mathrm{T}_{c}$ and effects of oxygen stoichiometry," Physica C, vol. 158, pp. 247-254, 1989.

[14] S. K. Agarwal, V. P. S. Awana, V. N. Moorthy et al., "Superconductivity above $90 \mathrm{~K}$ in low Tc phase $\mathrm{Bi}_{2} \mathrm{Ca}_{1} \mathrm{Sr}_{2} \mathrm{Cu}_{2} \mathrm{O}_{x}$," Physica C, vol. 160, no. 3-4, pp. 278-280, 1989.

[15] N. H. Wang, C. M. Wang, H. C. Kai, D. C. Ling, H. C. Ku, and K. H. Lu, "Preparation of $95 \mathrm{~K} \mathrm{Bi}_{2} \mathrm{CaSr}_{2} \mathrm{Cu}_{2} \mathrm{O}_{8+\delta}$ superconductor from citrate precursors," Journal of Applied Physics, vol. 28, no. 9, article L1505, 1989.

[16] T. Takabatake, W. Ye, S. Orimo et al., "Enhancement of superconductivity in $\mathrm{Bi}_{2} \mathrm{Sr}_{2} \mathrm{CaCu}_{2} \mathrm{O}_{8+\delta}$," Physica C, vol. 157, pp. 263266, 1989. 

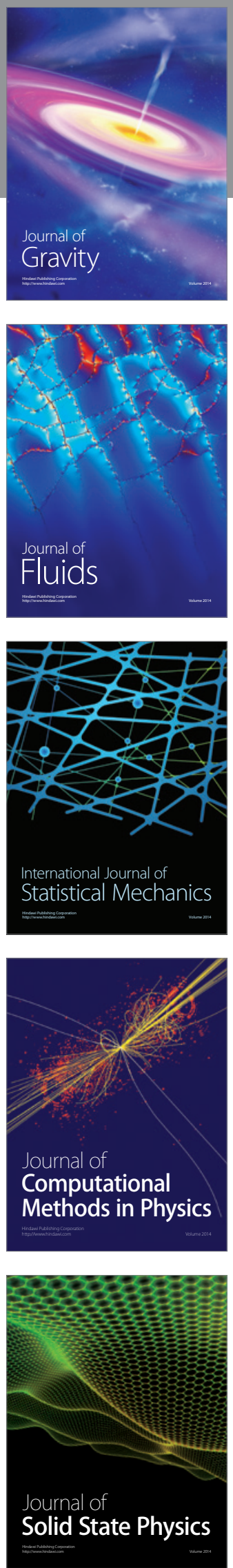

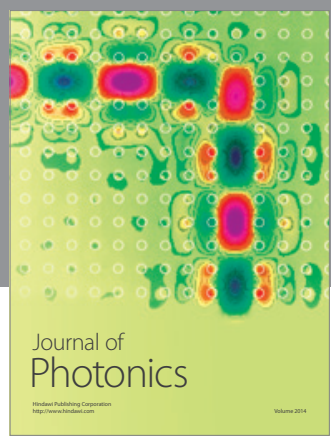

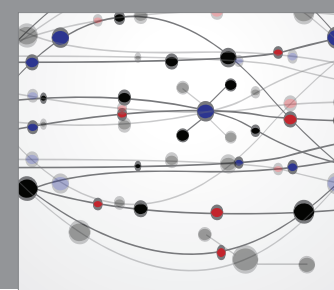

The Scientific World Journal

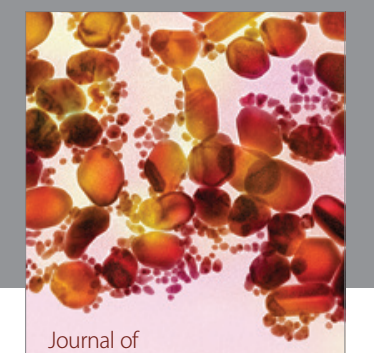

Soft Matter
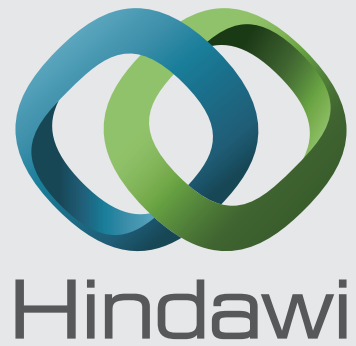

Submit your manuscripts at

http://www.hindawi.com
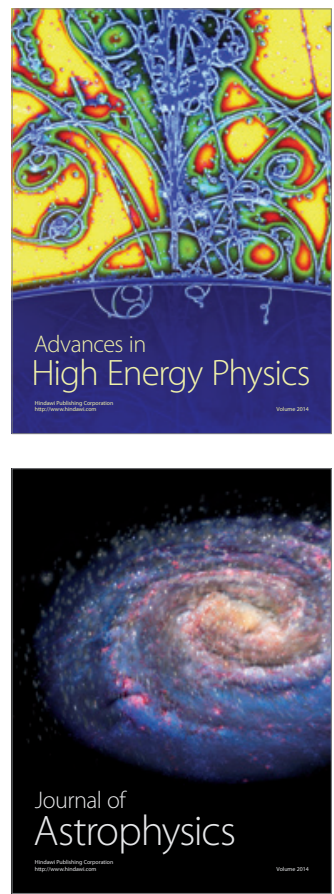
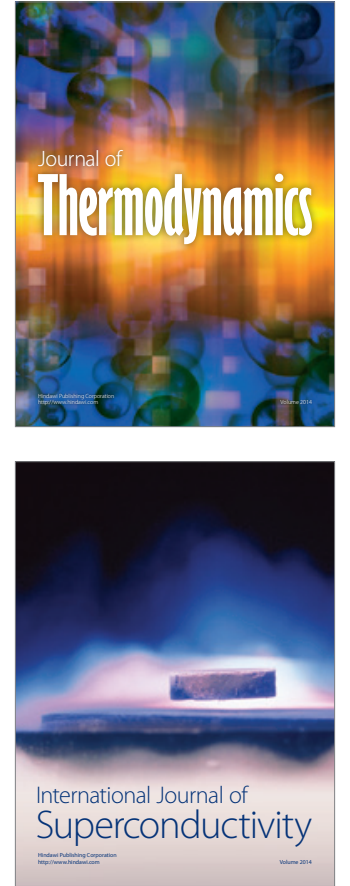
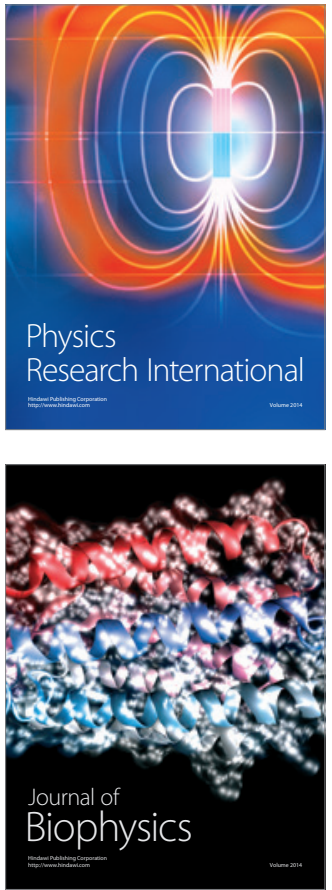
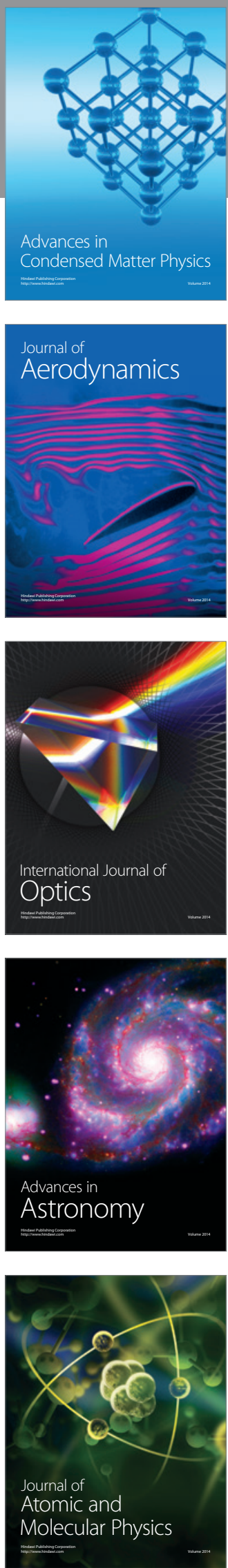